DOI: 10.32370/IA_2021_06_16

\title{
Results of an Experimental Test of the Establishment of Readiness of Future Officers-Psychologists to Serve in the Armed Forces of Ukraine
}

\author{
Yurkov Anatolii \\ https://orcid.org/0000-0002-7196-171X \\ Colonel, chief of the military humanitarian and linguistic faculty of the \\ Military Institute of Taras Shevchenko National University of Kyiv (Ukraine)
}

\begin{abstract}
The main tasks of the experimental work were: checking the pedagogical conditions identified on the basis of theoretical analysis of the establishment of readiness of future military psychologists for professional activity in the Armed Forces of Ukraine in the process of professional training; determining the dynamics of the establishment of readiness of future officers-psychologists for military service in the Armed Forces of Ukraine on the basis of developed criteria and indicators; performing statistical verification and confirming the results of experimental work; analyzing the results obtained and drawing conclusions and recommendations based on the results of the conducted pedagogical research.

The study was conducted on the basis of the Military Institute of Taras Shevchenko National University of Kyiv, the Military Academy (Odessa) and the Department of military training of the National Aviation University. Three/four-year cadets, attendees on the training of reserve officers, educators and officers were involved in the experimental work.

The given analysis of the components of readiness of future officers-psychologists of the Armed Forces of Ukraine for military service, namely: knowledge of theoretical material, motivation, emotional stability, endurance and communicative component have the root-mean-square results at the end of the experiment the analysis shows an increase in indicators by $10 \%$ in experimental groups relative to the control with the same indicators at the beginning of the experiment $58.5 \%$. The qualitative indicator in the control group increased by $13.5 \%$, and in the experimental group by $23.5 \%$.

Keywords. Experimental work; readiness of military psychologists; pedagogical experiment; professional training.

Вступ. Для вирішення проблеми формування готовності майбутніх офіцерівпсихологів до служби у Збройних Силах України в процесі спеціальної військової підготовки у вищому військовому навчальному закладі було підготовлено та проведено дослідно-експериментальну роботу. У результаті проведених досліджень було перевірено гіпотезу про те, що формування готовності майбутніх офіцерів-психологів до служби у Збройних Силах України буде дієвим при використанні визначених педагогічних умов, принципів і підходів педагогічної моделі формування готовності майбутніх психологів до служби у Збройних Силах України в процесі професійної підготовки у вищому військовому навчальному закладі.
\end{abstract}

Постановка завдання. Для вирішення зазначених завдань ми використовували 
такі методи дослідження: аналіз науково-методичної, спеціальної літератури; педагогічне спостереження та анкетування; проведення опитування, інтерв`ю, бесіди; моделювання ігрової діяльності; розробку професіографічного профілю майбутнього офіцера-психолога Збройних Сил України; формування знань, навичок та вмінь майбутнього офіцера-психолога як військового професіонала; визначення особистісних характеристик; моделювання реальної професійної діяльності; педагогічний формуючий експеримент; метод оцінки інтелекту; методи математичної статистики.

Мета статті. Відповідно до цілей і завдань досліджень, перевірки ефективності моделі формування готовності майбутніх психологів до служби у Збройних Силах України (далі ЗСУ) засобами інноваційних технологій у процесі професійної підготовки нами були проведені експериментальні дослідження.

Виклад основного матеріалу. Дослідження проводилось на базі Військового інституту Київського національного університету імені Тараса Шевченка, кафедри військової підготовки Національного авіаційного університету. До експериментальної роботи залучено курсантів 3-4-х курсів, студентів по підготовці офіцерів запасу, викладачів та офіцерів. Розкриємо етапи, зміст i методику проведення експериментальної роботи з формування готовності майбутніх психологів до служби у Збройних Силах України в процесі професійної підготовки. Експериментальна робота проводилась 32017 по 2020 роки і передбачала три етапи науково-педагогічного пошуку. Педагогічний експеримент складався 3 двох етапів (частин) констатувального та формувального. 3 метою визначення стану потреби у формуванні готовності майбутніх психологів до професійної діяльності у ЗСУ в процесі професійної підготовки проведено констатувальний педагогічний експеримент, в якому було задіяно 348 осіб зазначених ВВНЗ та ВНП(ЗВО).

Під час першого етапу (серпень 2017 р. - червень 2018 р.) проведено аналіз педагогічної, психологічної та філософської літератури з питань формування готовності майбутніх психологів до професійної діяльності у ЗСУ, виявлено суперечності між існуючою практикою професійної підготовки майбутніх офіцерів-психологів у ВВНЗ та ВНП(ЗВО) і можливостями виконання завдання в екстремальних та бойових умовах, а також психологічної реабілітації військовослужбовців учасників бойових дій; розроблено науковий апарат дослідження, визначено експериментальну базу, 
сформовано методологічний апарат дослідження. Також під час цього етапу було проведено констатувальний експеримент першого порядку, визначено педагогічні умови формування готовності майбутніх психологів до професійної діяльності у ЗСУ в процесі професійної підготовки та побудовано педагогічну модель цього процесу [1; 2; 6].

Другий етап (серпень 2017 р. - травень 2019 р.) передбачав проведення констатувального експерименту другого порядку. У цей час було сформовано дві групи: експериментальна (ЕГ) і контрольна (КГ).

В цілях коректного проведення експериментальних досліджень всі курсанти (студенти) були заздалегідь (до початку експерименту) вирівняні за основними показниками, які впливають на успішність засвоєння навчального матеріалу.

Курсанти (студенти)майбутні військові психологивирівнювалися за наступними показниками: 1) за успішністю по дисциплінах циклу загальної психолого-педагогічної та початкової військової підготовок; 2) за розумовими здібностями; 3) за суб'єктивним контролем; 4) за особливостями вольової саморегуляції; 5) за комунікативними і організаторськими здібностями; 6) за спрямованістю особи.

Всі перераховані показники підібрані були так, щоб вони відображали взаємозв'язок особових якостей і вимог майбутньої професійної діяльності військового психолога у ЗСУ.

Наголосимо, що окреслені параметри в обох групах піддавалися математичній обробці і прораховувалися за рівнем значимості по t критерію Стьюдента. Стан основних досліджуваних параметрів - їх відмінності виявилися недостовірними при $\mathrm{t}=$ 0,53; $<<0,95$, це дає підстави говорити про однорідність стартового стану груп і дає право приступити до експериментальних досліджень.

Слід зазначити, що для визначення професійної готовності до військової служби, фахових компетенцій, знань, навичок, вмінь майбутніх офіцерів-психологів ЗСУ в процесі становлення майбутніх офіцерів-психологів як професіоналів своєї справи було задіяно понад 450 респондентів (курсанти психологи, студенти військової кафедри за курсом підготовки офіцерів запасу психологічного напрямку) [1; 4].

Під час третього етапу (червень 2019 р. - грудень 2020 р.) було сформульовано висновки дослідження, узагальнено і систематизовано його матеріали; окреслено методичні рекомендації науково-педагогічним працівникам щодо формування 
готовності майбутніх офіцерів-психологів ЗСУ до військової служби.

Упровадження заходів формувального етапу експерименту відбувалось за рахунок організації в експериментальній групі (далі - ЕГ) спеціалізованого навчального курсу, використання інтерактивних форм, методів, освітніх ІКТ. Під час формувального експерименту активно застосовувались різноманітні засоби і методи педагогічного впливу, а також загальнонаукові теоретичні методи: абстракція, конкретизація, аналіз, синтез, порівняння, індукція, дедукція і моделювання. Ми виходили 3 методу системності, що дозволяє охопити явища, які вивчаються, у всіх їх взаємозв'язках [4; 5].

Знання теоретичного матеріалу оцінювалось в експериментальних та контрольних групах на початку експерименту за результатами контрольного зрізу знань iз навчальної дисципліни «Управління повсякденною діяльністю підрозділів» після вивчення першого модулю. Підсумковим результатом було зараховано результати рольової гри, яка проводилась після прочитаних лекцій повного навчального курсу «Управління повсякденною діяльністю підрозділів». Такі критерії як мотивація, емоиійна стабільність та витривалість, комунікативність, визначались на початку експерименту як у каральних так і в експериментальних групах за результатами двох практичних занять з навчальної дисципліни «Управління повсякденною діяльністю підрозділів». Підсумковим результатом оцінки формуючого педагогічного експерименту були критерії (мотивація, емоційна стабільність та витривалість, комунікативність) стала рольова гра «Організація внутрішньої служби та побуту в підрозділі» 3 навчальної дисципліни «Управління повсякденною діяльністю підрозділів». Отримані результати представлено у таблиці 1.

Результати формування готовності майбутніх офіцерів-психологів ЗСУ до військової служби (критерії оцінки) зображено графічно на рисунках 1, 2, 3 .

Висновки. Як видно із проведеного аналізу складових готовності майбутніх офіцерів-психологів ЗСУ до військової служби, саме: знання теоретичного матеріалу, мотивації, емоційної стабільності і витривалості, комунікативної середньо квадратичне результату на кінець експерименту показує збільшення показників на 10 \% у експериментальних групах відносно контрольних при однакових показниках на початку експерименту 58,5\%. Якісний показник у контрольній групі збільшився на 13,5\%, а в експериментальній групі на 23,5\%. Такі показники свідчать про ефективність 
Результати формування готовності майбутніх офіцерів-психологів ЗСУ до військової служби (критерії оцінки)

\begin{tabular}{|r|l|c|r|r|r|}
\hline \multirow{2}{*}{$\begin{array}{l}\text { No } \\
\text { I/I }\end{array}$} & \multirow{2}{*}{ Критерії оцінки } & \multicolumn{2}{|l|}{$\begin{array}{l}\text { На початок } \\
\text { експерименту }\end{array}$} & \multicolumn{2}{|l|}{$\begin{array}{l}\text { На кінець } \\
\text { експерименту }\end{array}$} \\
\cline { 3 - 6 } & & ЕГ & КГ & ЕГ & КГ \\
\hline 1 & $\begin{array}{l}\text { Знання } \\
\text { теоретичного } \\
\text { матеріалу }\end{array}$ & 68 & 67 & 78 & 92 \\
\hline 2 & Мотивація & 52 & 54 & 68 & 88 \\
\hline 3 & $\begin{array}{l}\text { Емоційна } \\
\text { стабільність } \\
\text { витривалість }\end{array}$ & 54 & 53 & 72 & 93 \\
\hline 4 & Комунікативність & 62 & 60 & 82 & 92 \\
\hline 5 & Середнє значення & 58,5 & 58,5 & 75 & 91,25 \\
\hline
\end{tabular}

розробленої нами педагогічної моделі формування готовності майбутніх офіцерівпсихологів ЗСУ до військової служби, та запропонованого дидактичного наповнення цієї моделі інноваційними педагогічними технологіями. Контрольними результатами стали підсумки рольової гри яка проводилась на навчальній дисципліні «Управління повсякденною діяльністю підрозділів».

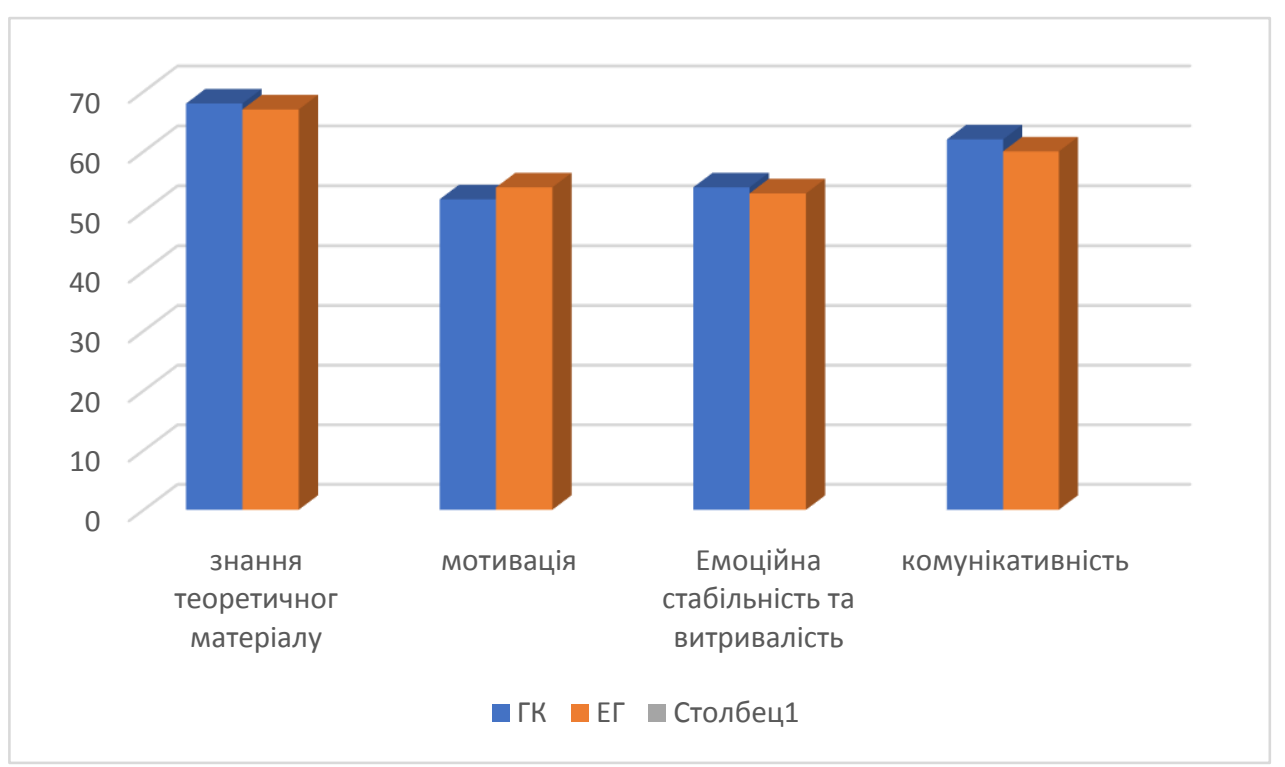

Рис. 1. Критерії оцінки готовності майбутніх офіцерів-психологів до військової служби до початку експерименту. 


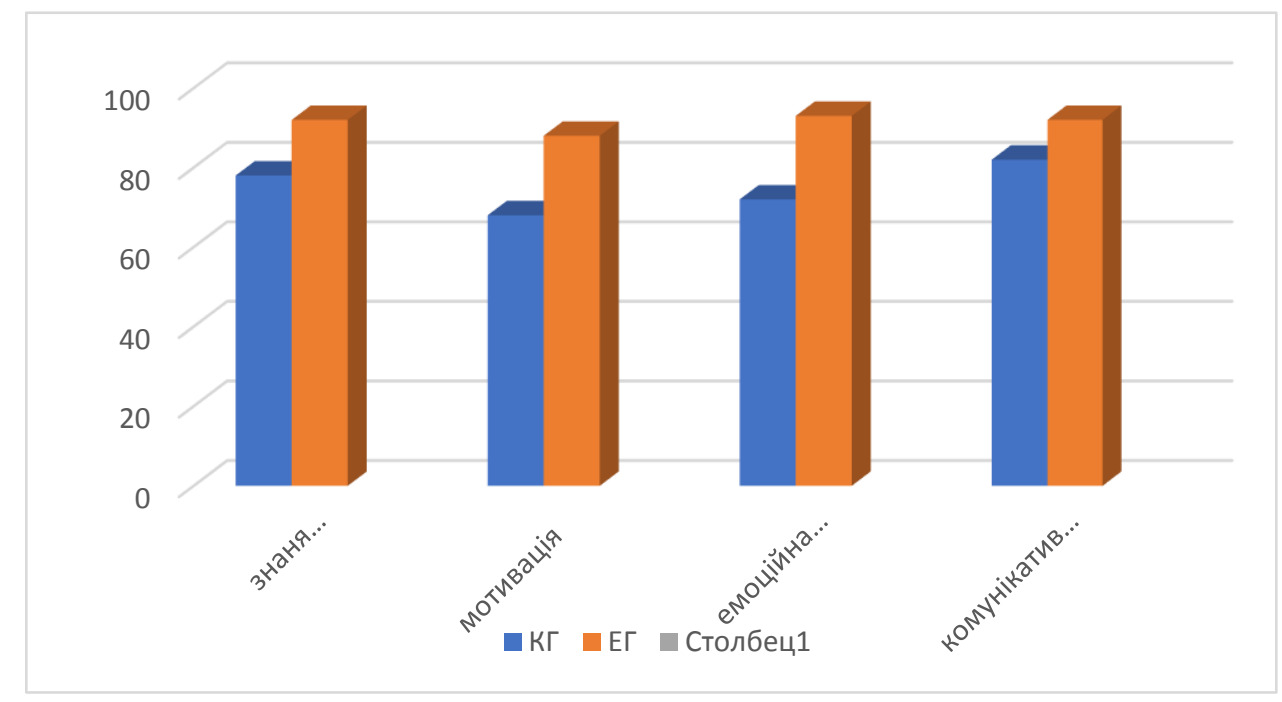

Рис. 2. Критерії оцінки готовності майбутніх офіцерів-психологів до військової служби на кінець експерименту.

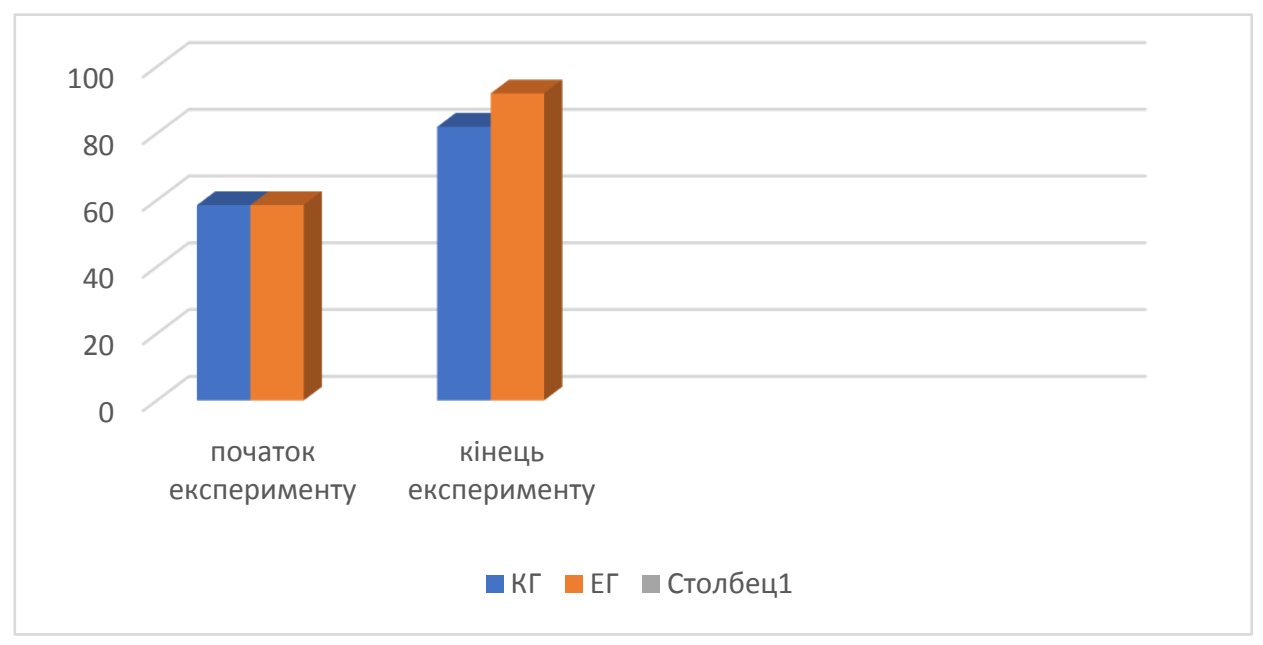

Рис. 3. Середня оцінка критеріїв готовності майбутніх офіцерів-психологів до військової служби до початку експерименту

\section{References}

1. Bondarenko O. V. Eksperymentalna perevirka formuvannia hotovnosti maibutnikh ofitseriv Zbroinykh Syl Ukrainy do profesiinoi diialnosti u viiskovykh litseiakh [Experimental verification of the formation of the readiness of future officers of the Armed Forces of Ukraine for professional activity in military lyceums]. Ukrainskyi pedahohichnyi zhurnal. 2020. No. 2. P. $131-141$.

2. Krushelnytska O.V. Metodolohiia ta orhanizatsiia naukovykh doslidzhen [Methodology and organization of scientific research] : navchalnyi posibnyk. Kyiv : Kondor, 2006. 206 p. 
3. Petko L.V. Vyklyky XXI stolittia dlia osvitnoho prostoru Ukrainy. Naukovi pratsi ChNU: nauk. zhurnal [The challenges of educational space in the $21-^{\text {st }}$ century]. 2017. Issue 303. Vol. 291. Pp. 10-14 (Pedahohika).

4. Prokhorov O. A. Eksperymentalna perevirka pedahohichnykh umov ta tekhnolohii hotovnosti maibutnikh ofitseriv do profesiinoi diialnosti na zasadakh pedahohichnoho menedzhmentu [Experimental verification of pedagogical conditions and technology of readiness of future officers for professional activity on the basis of pedagogical management]. Zbirnyk naukovykh prats Viiskovoho instytutu Kyivskoho natsionalnoho universytetu imeni Tarasa Shevchenka. No. 27. P. 322-332.

5. Ryzhykov V.S. Znachennia profesiinykh yakostei $v$ tsilovii modeli navchalnovykhovnoho protsesu pidhotovky viiskovykh [The value of professional qualities in the target model of the educational process of military training]. Visnyk Kyivskoho natsionalnoho universytetu imeni Tarasa Shevchenka: sotsialna robota. 2017. No. 2. P. 61-64.

6. Tolok I. Metodyka provedennia eksperymentalnoho doslidzhennia formuvannia psykholoho - pedahohichnoi kompetentnosti viiskovykh fakhivtsiv operatyvno - taktychnoho rivnia pidhotovky [Methods of conducting experimental research on the formation of psychological and pedagogical competence of military specialists of operational and tactical level of training]. Suchasni informatsiini tekhnolohii ta innovatsiini metodyky navchannia u pidhotovtsifakhivtsiv: metodolohiia, teoriia, dosvid, problemy. 2012. Issue 33. P. 37-40. URI : http://nbuv.gov.ua/UJRN/.

7. Bakhov I., Ryzhykov V., Kolisnyk O. Leadership Abilities of a Military Manager, Professionalism of a Commander as the Guarantee of the Practice of Effective Activity of a Military Organization. International Journal of Engineering \& Technology. 2018. Vol 7. No 4.38: Special Issue 38. P. 45-49.

8. Ryzhykov V. Method of organizing lessons in the armies in the way of modern world military educational practice. Problems of the development of modern science: theory and practice: Collection of scientific articles. EDEX, Madrid, España, 2018. P. 218-228

Translation of the Title, Abstract and References to the Author's Language

Анотація

УДК 378:355.014

Юрков Анатолій. Результати експериментальної перевірки формування готовності майбутніх офіцерів-психологів до служби у Збройних Силах України.

Основними завданнями експериментальної роботи були: перевірка виявлених на основі теоретичного аналізу педагогічних умов формування готовності майбутніх військових психологів до професійної діяльності у ЗСУ в прочесі професійної підготовки; визначення динаміки формування готовності майбутніх офічерівпсихологів до військової служби у ЗСУ на основі розроблених критеріїв і показників; здійснення статистичної перевірки та підтвердження отриманих результатів експериментальної роботи; аналіз отриманих результатів і формулювання висновків та рекомендацій за результатами проведеного педагогічного дослідження.

Дослідження проводилось на базі Військового інституту Київського національного університету імені Тараса Шевченка, Військової академії (м. Одеса) та 
кафедри військової підготовки Національного авіащійного університету. До експериментальної роботи залучено курсантів 3-4-х курсів, слухачів по підготовці офічерів запасу, викладачів та офічерів. Проведений аналіз складових готовності майбутніх офіцерів-психологів ЗСУ до військової служби, саме: знання теоретичного матеріалу, мотивації, емоційної стабільності $i$ витривалості, комунікативної середньо квадратичне результату на кінець експерименту показує збільшення показників на 10\% в експериментальних групах відносно контрольних при однакових показниках на початку експерименту 58,5\%. Якісний показник у контрольній групі збільшився на 13,5\%, а у експериментальній групі на 23,5\%.

Ключові слова: експериментальна робота, готовність військових психологів, педагогічний експеримент, професійна підготовка.

\section{Лimepamypa}

1. Бондаренко О. В. Експериментальна перевірка формування готовності майбутніх офіцерів Збройних Сил України до професійної діяльності у військових ліцеях. Український педагогічний журнал. 2020. № 2. С. 131-141.

2. Крушельницька О. В. Методологія та організація наукових досліджень : навчальний посібник. Київ : Кондор, 2006. 206 с.

3. Петько Л.В. Виклики XXI століття для освітнього простору України. Наукові праці ЧНУ: наук. журнал / Чорном. Нац. ун-т ім. Петра Могили; ред. кол.: О.П.Мещанінов (голова) [та ін.]. Миколаїв : Вид-во ЧНУ імені Петра Могили, 2017. Т. 303. Вип. 291. С. 10-14 (Педагогіка).

4 Прохоров О. А. Експериментальна перевірка педагогічних умов та технології готовності майбутніх офіцерів до професійної діяльності на засадах педагогічного менеджменту. Збірник наукових пращ̧ь Військового ін-ту Київського нац. ун-ту імені Тараса Шевченка. 2010. № 27. С. 322-332.

5. Рижиков В. С. Значення професійних якостей в цільовій моделі навчальновиховного процесу підготовки військових. Вісник Київського нац. ун-ту імені Тараса Шевченка: Соціальна робота. 2017. № 2, С. 61-64.

6. Толок I. В. Методика проведення експериментального дослідження формування психолого - педагогічної компетентності військових фахівців оперативно - тактичного рівня підготовки. Сучасні інформаційні технологї та інноваційні методики навчання у підготовиі фахівиів: методологія, теорія, досвід, проблеми. 2012. Вип. 33. С. 37-40. URI : http://nbuv.gov.ua/UJRN/

7. Bakhov I., Ryzhykov V., Kolisnyk O. Leadership Abilities of a Military Manager, Professionalism of a Commander as the Guarantee of the Practice of Effective Activity of a Military Organization. International Journal of Engineering \& Technology. 2018. Vol 7. No 4.38: Special Issue 38. P. 45-49.

8. Ryzhykov V. Method of organizing lessons in the armies in the way of modern world military educational practice. Problems of the development of modern science: theory and practice: Collection of scientific articles. EDEX, Madrid, España, 2018. P. 218-228 